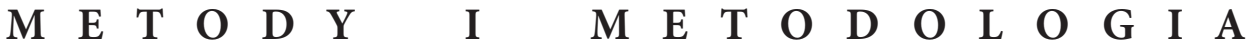

Archeologia Polski, LXVI: 2021

PL ISSN 0003-8180

DOI: $10.23858 /$ APol66.2021.003

STANISŁAW TABACZYŃSKI

\section{SOME OBSERVATIONS ON PALAEOSOCIOLOGY, SOCIAL INTERACTIONS, POLYSEMANTISATION OF CULTURE AND THE THEORETICAL WRITINGS OF LEO KLEJN FROM THE POLISH PERSPECTIVE}

\begin{abstract}
The text contains reflections on important issues in the field of archaeological theory such as the polysemantisation of culture and concerning palaeosociology, which use archaeological and ethnographical data to study historical social interactions and to broaden knowledge on social determinants studied by historical sociology. Among other things, these issues were made the subject of in-depth reflection by Leo S. Klejn, who defined the area under study as archaeosociology. When organizing anthropological (ethnographic) and archaeological data, we should take into account the mutual relations between complementary perspectives as conscious expressions and unconscious foundations of social life. To do this, it is helpful to apply the concept of cultural polysemantisation, which allows the study of societies without limiting starting assumptions. Artefacts may indicate noteworthy manifestations of past social structures.
\end{abstract}

Keywords: archaeological theory, historical sociology, archaeosociology, polysemantisation of culture, source theory, archaeology, social interactions

\begin{abstract}
Abstrakt: Tekst zawiera refleksje na temat istotnych zagadnień z zakresu teorii archeologii, takich jak polisemantyzacja kultury i paleosocjologia, w których dane archeologiczne i etnograficzne wykorzystywane są do badania historycznych interakcji społecznych oraz do pogłębiania wiedzy o uwarunkowaniach społecznych badanych przez socjologię historyczną. Między innymi te zagadnienia uczynił przedmiotem namysłu Leo S. Klejn, określający badany obszar jako archeosocjologię. Organizując dane antropologiczne (etnograficzne) i archeologiczne, powinniśmy uwzględniać wzajemne relacje między uzupełniającymi się perspektywami, rozumianymi jako świadome wyrażenia i nieświadome podstawy życia społecznego. By to uczynić, pomocne jest zastosowanie koncepcji polisemantyzacji kultury, która pozwala na badanie społeczeństw bez ograniczających założeń wyjściowych. Artefakty mogą wskazywać na warte uwagi przejawy funkcjonowania dawnych struktur społecznych.
\end{abstract}

Słowa kluczowe: teoria archeologii, socjologia historyczna, archeosocjologia, polisemantyzacja kultury, teoria źródeł, archeologia, interakcje społeczne 


\section{INTRODUCTION $^{1}$}

Archaeological and ethnographic data might be employed in studies of historic societal interactions and for the development of a historical sociology "with its generalization of historical process and its formulation of historical laws", as it was formulated by Leo Klejn. I propose below the use in such investigations the of the idea of polysemantisation of culture (Piekarczyk 1971; Tabaczyński 2010), because this concept allows for better understanding, not only of certain features of the process of social changes that have until now not been fully recognized, but also the archaeological expressions of social interactions associated with it. In a wider context, this concept provides an essential correcting factor to Lévi-Strauss' opinion about the relationship between history and ethnology and it should also be considered in anthropological and archaeological approaches in order to examine past social changes. Thus, we should look differently at the mutual relationships between the two complementary perspectives organizing anthropological (ethnographic) and archaeological data: conscious expressions and unconscious foundations of social life (Tabaczyński 2006).

The use of the concept of the polysemantisation of culture allows for investigations of societies without script where the artefacts indicate social status and therefore should be treated as conscious expressions of social structures of the time. This approach is a modest supplement to the ideas of Leo Klejn. As I have already written in 2004 in the book dedicated to the scholar, although, as it happens, I have never had the opportunity to actually meet Professor Klejn in person, we haven't been isolated (Tabaczyński 2004). In 1972, our two short studies about the European Neolithic were published together in the same first volume of Neolithische Studien (thanks to the initiative of Hermann Behrens from Halle; see Klejn 1972; Tabaczyński 1972). In subsequent years I was involved in a systematic reading of Leo Klejn's works, and I followed with particular interest all the threads concerning the problem of archaeological evidence and its interpretation in social terms.

Because of the potential wide scope of the subject matter, this article is focused on the strictly selected aspects of palaeosociology / archaeosociology, such as the specific nature of archaeological sources and archaeology as a s o u r c e - s t u d y ing socio-historical discipline; the issue of the polysemantisation of culture, as well as the role of Marxist thought as reflected in Klejn's works.

1 The content of this article was developed by the late Stanisław Tabaczyński (1930-2020) at the Theoretical Archaeology Group session titled „Debating Principles of Archaeological Interpretation. An Examination of the Work of Leo S. Klejn" as part of the international conference of the Theoretical Archaeology Group, which took place in 2011 in Birmingham. The session was organized by Ludomir R. Lozny (Hunter College) and Stephen Leach (Keele University). The arguments proposed by Stanisław Tabaczyński for print were presented there at the Professor's request by Anna I. Zalewska and were well received, also by Leo S. Klejn himself. 


\section{ARCHAEOSOCIOLOGY AS AN INTEGRAL PART OF INVESTIGATIONS OF THE PAST}

In 1978 and 1979, I was teaching at the Sorbonne (Université Paris I, Panthéon Sorbonne) as maitre de conférences and the topic of my French seminars was closely connected with problems of the social interpretation of stratigraphic sequences. In that period, I had the opportunity to discuss some problems of "archaeosociology" with Carl-Axel Moberg, who at that time was also visiting professor there.

As Ian Hodder (2007, p. 26) writes: "In recent decades not only the mind, but even economy and the environment have come to be seen as social. The body and sex too, have been pried from biology and placed firmly in the social realms, the overall goal of interpretation in archaeology has come to be to understand the past in social terms". An analysis of Leo Klejn's works seems to fully confirm this opinion.

"Archaeosociology" constitutes an integral part of the basic principles of the archaeological investigations of the past. According to Klejn's works "archaeosociology" creates - together with "archaeological history" and with "archaeological ethnogenetics" - a Trivium which in the Soviet archaeology united three directions of research, which have - according to Klejn - a common characteristic quality. They all look for the foundation of theoretical apparatus outside archaeology proper (that is in history, sociology or linguistics). As Klejn writes, we are dealing here with an archaeology that is broadly conceived, not strictly delimited, that is "not really" archaeological.

\section{THE SPECIAL NATURE OF ARCHAEOLOGICAL SOURCES}

Another fundamental aspect in the process of studying archaeosociology (also in Klejn's works), is the place of archaeology as a "source-studying [...] socio-historical discipline". According to Klejn (see 1978, pp. $39 \mathrm{ff}$.), the specific nature of the archaeological source is defined by two characteristics. One of these is its $\mathrm{m}$ a t e rial nature which each time requires translation of the information it carries, from the level of directly empirically observable objects to that of an abstract system of signs in a defined language. It is this characteristic that differentiate it from a written source.

The second basic characteristic is a generally irrevocable exclusion from social use, connected with a break in continuity and tradition of use. Being forgotten - as is noted by L.S. Klejn (1978, p. 60) is quantitatively difficult to measure, but is demonstrable. After crossing a certain stage, a thing becomes difficult to understand, this characteristic differentiates archaeological sources from ethnographic information.

The formation of the archaeological source is continuous, although not at a constant rate in time and space. It is a process of cumulative deposition of things which man creates, transforms, accumulates, and leaves behind. The preserved part of these material correlates of human presence and activity become, upon their progressive discovery, a source of information about the social past. 
The creation of the written record, on the other hand is discontinuous and evidently intermittent in time and space. It is a process of making information permanent, with the intention of its transmission to contemporaries and / or descendents. Thus in this manner the written record (where it is present), partially overlaps with the potentially enormous and continuously generated mass of archaeological material.

In Jerzy Topolski's classification, archaeological evidence belongs to the category of direct sources which differ from written sources because they render possible direct cognition; concern facts; need no intermediary of a third person; (where authenticity is assured) involve no problem of examining their reliability; have the character of symptoms, and fulfill a mediating function in the relationship: "past present - past", but do not have persuasiveness (see for example Topolski 1983, pp. 260-261; idem 1996, p. 47).

More archaeologists are now prepared to substitute the previously dominating substantial approach with a structural one using a semiotic description of cultural reality. This has given the impetus to new ways of conceptualizing archaeological evidence. In historiography, the change of perspective is expressed most suggestively by Michel Foucault dealing with notions of "document" and "monument", and the relationship between them both (Foucault 1969; 1977). The traditional understanding of the document, as Jacques Le Goff (commenting on Foucault) underlined, contains the concept "docere", the deliberate making permanent of information with the purpose of transmitting it to someone else. The document is conceived as something which informs us of that which concerns the author of the text. In reality a document is de facto always a monument. It is something which shapes, and not what informs with a purpose creating an impression (Le Goff 1982, p. 102).

The interpretation of Le Goff allows us to understand more clearly the meaning of Foucault when he writes that history today is that which transforms "documents" into "monuments" and that which (where traces left by people are being read) uncovers an assembly of elements that should be distinguished, divided into groups, evaluated, linked together, joined into entities. He also states that whilst archaeology gains sense only by reproduction of historical discourse, so now history is tending toward archaeology - towards the intrinsic description of the monument.

As the result of this "transformation of documents into monuments" as Jerzy Topolski notes (1983, p. 265), the historian more often reaches for the "informative structure of symptomatic character" by which the superficial information of the source become an indicator of other deeper hidden information. On the other hand, we observe attempts, especially by the adherents of the school of "symbolic - structural" archaeology, to demonstrate the richness and complexity of "sign information structures" that had been previously not fully observed. The vehicle of these can be also objects of everyday use, a theme previously examined by semiotic studies in art history (Maltese 1970).

Just as the historian transforms "documents" into "monuments", the archaeologist does the opposite - "monuments" might appear to him as "documents". So the scholars meet halfway, crossing the demarcation which until recently in the consciousness of many researchers sharply divided archaeological and written sources. 
This makes possible a more objective confrontation, not of the types of the sources themselves, but of the information contained in them. The tendency to achieve the fullest utilization of the archaeological sources continues. This has led to a detailed analysis of the relationship between indicat or s and indicata and the use of the approaches of ethnomethodology.

\section{POLYSEMANTISATION OF CULTURE AND ITS ROLE IN THE INTERPRETATION OF THE SOCIAL PAST}

A theme that I feel is especially significant in the social interpretation of archaeological evidence is the recognition of the role of the polysemantisation of culture (Piekarczyk 1971; Tabaczyński 2010). In the interpretation of archaeological sources, three factors are of fundamental importance: the sample space, the quality of the knowledge that the observer has and which has been applied in the programme that we are realizing. This is particularly important when the object of research is societies that are undergoing constant and regular transformations.

Such a transformation is the process of the progressive polysemantisation of culture of human groups. This has been occurring on a global scale from at least the end of the Neolithic when we see changes occurring in groups having previously egalitarian social structures and monosemantic cultures. We see the beginning and further development of social inequality (rank revolution; rivoluzione "del rango"), the formation of an elite, differentiation of social status, ideologies and attitudes within the communities which until then appear to have been internally homogenous. The wide range and intensity of the appearance of the indicators of the process - such as rich graves, hoards (and elements such as figural representations including rock engravings and figural sculptures), give a picture of the spread and dynamics of the phenomenon of social differentiation. One of the most significant appears to be the emergence of the high status warriors, among them on horseback, armed with spears, shields, battle axes and swords. Their appearance is an indicator of the beginnings and development of the processes that culminated in the formation of the Early State.

In contrast to models that see the past merely as a succession of internally homogeneous "cultures", the archaeological record of the group with a polysemantic culture is highly complex. In order to understand such a multifaceted record, we must considerably broaden the space of observation, the dimensions of which should embrace all the various forms of fossil correlates. For example, in the case of Central European early medieval centres these are: strongholds, suburbs, service settlements, hoards, graves and monuments. These are all reciprocally linked in a functional and structural sense and cannot be analyzed separately. In the case of a polysemantic culture group, the diagnosis and explanation should be formulated, examined and explained in the terms proper to the specific character of the undertaken problem. In that case, the proper approach is treating it in social terms. 
Table 1. The monosemantic and polysemantic cultures form the poles of a continuum within which the specific research situations can be placed. The fossil correlates left behind by these culture groups are quite different

\begin{tabular}{|l|l|}
\hline \multicolumn{1}{|c|}{ Group with monosemantic culture } & \multicolumn{1}{c|}{ Group with polysemantic culture } \\
\hline \hline A social group internally undifferentiated. & $\begin{array}{l}\text { A system consisting of at least two sub- } \\
\text { groups differing is social status and having } \\
\text { available a union of information. } \\
\text { The information is shared partly by all }\end{array}$ \\
$\begin{array}{l}\text { To all members is available a union of } \\
\text { interiorized information transmitted in the } \\
\text { form of generally comprehensible messages. }\end{array}$ & $\begin{array}{l}\text { mers of the group and transmitted } \\
\text { fes in an union of semiotic systems. } \\
\text { This information articulates the world }\end{array}$ \\
$\begin{array}{l}\text { This information articulates the world and } \\
\text { and programs the activity of all mem- } \\
\text { bers of the group in an identical way. }\end{array}$ & $\begin{array}{l}\text { ups in such a way, that some of the standards } \\
\text { of behavior are shared by all subgroups, } \\
\text { while others are confined to some of them. }\end{array}$ \\
\hline
\end{tabular}

\section{MARXISM IN RUSSIAN AND POLISH ARCHAEOLOGY: NEITHER CRADLE NOR GRAVE}

As is widely-recognised, for over a century a critical engagement, in one form or another, with the notions embodied in Marxism has been an indispensable part of social science. When asked if he was an orthodox Marxist, Leo Klejn replied: "whether orthodox, I don't know, but for a short time I was". Such a statement, however should be considered as a starting point rather than a summary of Klejn's theoretical position. Elsewhere he stated that his "short affair with Marxism did not leave" him "without trace", and indeed, it is easy to perceive this in many of his theoretical writings.

Klejn himself does not conceal his doubts about the existence of a purely Marxist archaeology. It seems to me, however, that it is worth posing the question: is it possible to have a social science today which has no basis in Marxist thought? By this, I mean of course, the Marxism that is an imminent part of the European intellectual heritage (and not that which became a political tool that was often over-exploited to a degree which was criminal). Leo Klejn (like Andrzej Walicki, see 1996) clearly sees the difference between these two. His acceptance of Marxism, together with his bold rejection of the whole Soviet system, was one of the factors which led to a recognition of the values of his work in many Central European milieu. Nevertheless, the basic question remains open: to what degree was the Marxist paradigm a formative factor in Russian and in Polish post-war archaeology (for more detail of this see Barford 2004) and does it have any future in this part of Europe (see Tabaczyński 1995)?²

${ }^{2}$ See also the development of the thread on the attitude of Stanisław Tabaczyński to Marxism in: Cyngot, Zalewska 2019, pp. 190-192. 


\section{INSTEAD OF A CONCLUSION}

In conclusion of this brief article, it is possible to demonstrate the convergence of some of Klejn's theoretical ideas and those developing in Central European archaeology. These concern the nature of archaeological sources and some of the main problems of their interrogation in social terms, including the roles of Marxist thought conceived as a theory of social relations. An important role here is played by a consideration of the implications of processes of social differentiation and the consequent polysemantisation of culture. This issues could be, I hope, a modest but real supplement to the idea of palaeosociology as treated by Leo Klejn and others.

Prepared for print by Anna I. Zalewska, Paul M. Barford and Dorota Cyngot

\section{BIBLIOGRAPHY OF WORKS CITED}

B a r ford P. 2004, Polish archaeology and Marxism: just a passing phase?, [in:] Arheolog: detektiv i myslitel' / The archaeologist: detective and thinker: sbornik stat'ei, posvyashchennyi 77-letiyu L'va Samoilovicha Kleina, L.B. Vishnyatskii, A.A. Kovalev, O.A. Shcheglova eds., Sankt-Peterburg, pp. 182-197.

Cyngot D., Z a lew ska A.I. 2019, A life in archaeology and the specificity of archaeological research. Encounters with Stanisław Tabaczyński, "Archaeologia Polona", 57, pp. 185-205.

F o u c a u lt M. 1969, Larchéologie de savoir, Paris.

F o u c a u lt M. 1977, Archeologia wiedzy, Warszawa.

H o d d e r I. 2007, The "Social" in archaeological theory: An historical and contemporary perspective, [in:] A companion to social archaeology, L. Meskell, R.W. Preucel eds., Malden, pp. 23-42.

Klejn L. 1972, Die Konzeption des Neolithikums, Äneolithikums und der Bronzezeit in der archäologischen Wissenschaft der Gegenwart, [in:] Neolithische Studien I, L.S. Klejn, S. Tabaczyński, K. Kroitzsch eds., Berlin, pp. 7-30.

Kle j n L.S. 1978, Arheologicheskie istochniki: Uchebnoe posobie, Leningrad.

L e G off J. 1982, Intervista sulla storia, a cura di Francesco Maiello, Rome-Bari.

Malt e s e C. 1970, Semiologia del messagio oggettuale, Milan.

P i e k a r zyk S. 1971, Z problemów polisemantyzacji kultury: próba konstrukcji modelu, "Studia Źródłoznawcze. Commentationes", 16, pp. 1-24.

Ta b a c z y ń s k i S . 1972, Gesellschaftsordnung und Güteraustausch im Neolithikum Mitteleuropas, [in:] Neolithische Studien, I, L.S. Klejn, S. Tabaczyński, K. Kroitzsch eds., Berlin, pp. 31-96.

Ta b a c z y ń s k i S. 1995, A future for the Marxist paradigm in Central European archaeology? The Polish case, [in:] Whither archaeology?, M. Kuna, N. Venclová eds., Praha, pp. 69-81.

Ta b a c z y ń ski S. 2004, Coconstructing the past: the cognitive status of archaeological evidence, [in:] Arheolog: detektiv i myslitel' / The archaeologist: detective and thinker: sbornik 
statei, posvyashchennyi 77-letiyu L'va Samoilovicha Kleina, L.B. Vishnyatskii, A.A. Kovalev, O.A. Shcheglova eds., Sankt-Peterburg, pp. 105-113.

Ta b a c z y ń s k i S. 2006, Archaeology-anthropology-history. Unconscious foundations and conscious expressions of social life, "Archaeologia Polona", 44, pp. 15-39.

Ta b a c z yńs ki S. 2010, Processes of polysemantisation of culture and their fossil correlates, [in:] Rola głównych centrów kulturowych w kształtowaniu oblicza kulturowego Europy środkowej we wczesnych okresach epoki żelaza, B. Gediga, W. Piotrowski eds., BiskupinWrocław, pp. 13-25.

To p olski J. 1983, Teoria wiedzy historycznej, Poznań.

To p ols k i J. 1996, Jak się pisze i rozumie historię. Tajemnice narracji historycznej, Warszawa. Wali cki A. 1996, Marksizm i skok do królestwa wolności. Dzieje komunistycznej utopii, Warszawa.

STANISŁAW TABACZYŃSKI

\section{KILKA UWAG O PALEOSOCJOLOGII, RELACJACH SPOŁECZNYCH, POLISEMANTYZACJI KULTURY I TEORETYCZNYCH PRACACH LEO KLEJNA - Z POLSKIEJ PERSPEKTYWY}

\section{Sum mary}

Autor omawia zagadnienia polisemantyzacji kultury i paleosocjologii, istotne dla teorii archeologii. Polisemantyzacja obrazuje proces rosnącej złożoności społeczeństw. Paleosocjologia wykorzystuje dane archeologiczne i etnograficzne do badania historycznych interakcji społecznych oraz do pogłębiania wiedzy o uwarunkowaniach społecznych, będących tematem studiów socjologii historycznej. Zagadnienia te stanowiły również przedmiot rozważań Leo S. Klejna, który określał ów obszar jako archeosocjologię. W artykule, będącym skromnym uzupełnieniem idei Klejna, zaproponowano zastosowanie idei polisemantyzacji kultury do badań przeszłości. Jak można sądzić, koncepcja ta pozwala lepiej zrozumieć pewne, do tej pory nie w pełni rozpoznane cechy procesu przemian społecznych i związane z tym społeczne interakcje, po których pozostają materialne przejawy możliwe do badania metodami archeologii. W szerszym kontekście idea ta stanowi istotny czynnik korygujący zastane teorie stosowane w archeologii. Pod uwagę wzięta została opinia C. Lévi-Straussa o relacjach między historią a etnologią - niezbędnych do uwzględnienia w badaniach przeszłych zmian społecznych. Zmiany te każdorazowo pozostawiają dane materialne, możliwe do rozpoznania archeologicznego. Dlatego, organizując dane antropologiczne (etnograficzne), historyczne i archeologiczne, powinniśmy spojrzeć na uzupełniające się perspektywy badawcze jako na relacje między świadomymi wyrażeniami i nieświadomymi podstawami życia społecznego. By to czynić w sposób możliwie kompletny, pomocne jest stosowanie koncepcji polisemantyzacji kultury, która pozwala na badanie społeczeństw bez ograniczających założeń wyjściowych. Artefakty mogą wskazywać na warte uwagi przejawy funkcjonowania struktur społecznych. 